\title{
Toward an Integrative Theory of Self-Identity and Identity Stressors and Traumas and Their Mental Health Dynamics
}

\author{
Ibrahim Kira1,2 \\ ${ }^{1}$ Center for Cumulative Trauma Studies, Stone Mountain, GA, USA \\ ${ }^{2}$ Center for Stress, Trauma and Resiliency, Georgia State University, Atlanta, GA, USA \\ Email: kiraaref@aol.com
}

How to cite this paper: Kira, I. (2019). Toward an Integrative Theory of SelfIdentity and Identity Stressors and Traumas and Their Mental Health Dynamics. Psychology, 10, 385-410. https://doi.org/10.4236/psych.2019.104027

Received: January 26, 2019

Accepted: March 3, 2019

Published: March 6, 2019

Copyright $\odot 2019$ by author(s) and Scientific Research Publishing Inc. This work is licensed under the Creative Commons Attribution International License (CC BY 4.0).

http://creativecommons.org/licenses/by/4.0/

\section{c) (i) Open Access}

\begin{abstract}
Self-identity is a flexible and linear/non-linear dynamic system that consists of various identities and hierarchical sub-modules and operating processes and develops (grows or declines) through dealing with stressors and traumas (IST). ISTs may threaten the existence, the maintenance or development of one of the persons' identities. Different IST types include personal identity, physical identity, role identity, and social identity stressors/traumas and constitute a multi-level hierarchy. A value processing system, related selfevaluation, and core developmental assets are identity-impeded operational processes in each identity. The salience of one identity may be activated by IST and became the situational (or the default) lens that biases the person's appraisal and coping response. The most traumatizing ISTs are those that threaten identities' existence, triggering existential anxieties. The macro dynamics of accumulation, proliferation and the interaction between pre-identity, identity, and post-identity traumas determine their mental health impact, rather than a triggering trauma.
\end{abstract}

\section{Keywords}

Identity Traumas, Existential Annihilation Anxiety, Developmental Assets, Value Processing System (VPS), Development-Based Trauma Framework (DBTF)

\section{Introduction}

Self-identity, the executive self, develops within the context of adversities. Advancing our understanding of self and identity in the context of life stressors and traumas is important to develop the field. Authors want to state from the begin- 
ning that they consider traumatic events as one type of stressors that are acute and are an intricate part of the general theory of stressors. When we talk about stressors, we mean all kinds of acute (traumatic), chronic and non-chronic stressors. Further, we think that clinical science should focus on the impact and the total macro dynamics of stressors that include the accumulation and proliferation of traumatic, chronic and non-chronic stressors, their dynamical interactions and their impact and not only on a single acute (traumatic) stressors which are, mostly the dominant focus of the single trauma-focused PTSD literature. We will discuss in detail the current perspective of Self- and identity stressors and the need for new perspective and propose an integrative framework that details identity traumas and their micro and macro dynamics.

There are growing interest and momentum and emerging body of literature around, stress, identity, and trauma. However, their diverse empirical findings and conceptual paradigms are fragmented which challenge their conceptual clarity. The conceptual and empirical integration that combine and refine the various models is vital to moving the field forward. The goal of the current paper is to propose a unifying and coherent interdisciplinary framework that may enhance the conceptual precision and absorbs/integrates the diverse theories and the rich empirical findings on identity, stressors, and traumas and their mental health dynamics. This project can provide clarity while also generating new testable ideas. We will briefly describe the current perspective on identity and identity stressors and traumas, and then propose a refined and integrative conceptual framework for the mechanisms of interaction between identity and identity/stressors and their linear and non-linear micro and macro dynamics.

\section{The Current Perspective on Self-Identity and Identity Stressors and Traumas and the Need for a New Framework on Identity Stressors and Traumas}

Current status of our knowledge in this field reflected significant progress on understanding identity/stressor/trauma dynamics. Individuals develop their identities, starting in early adolescence (e.g., Blos, 1962; Kroger, 2007). Adolescence marks the crucial individuation revolution that sets the child on the developmental path and the emergence of a unique interdependent person into adulthood. Self-identity as a flexible and dynamic agentic system develops (positively or negatively) by dealing with internal, environmental and social stressors and traumas. There is evidence that the activation of self-identity is context specific and varies across situations and with the exposure to the developing context of stressors and traumas (e.g., Galliher, McLean, \& Syed, 2017; Guala \& Filippin, 2017). Identity stressors and traumas are the context of and pre-requisite to identity development and constitute the other term of the identity development equation. The response of the emerging identity to the challenging or threatening internal and external stressors and traumas determines the trajectory of identity development and its behavioral outcomes. Stressors can challenge or nurture one aspect of self-identity, stimulating or inhibiting its development. For 
example, rape can challenge and inhibit the personal identity autonomous growth, while nurturing family environment can nurture personal identity autonomy and interdependence.

At adolescence, individuals start acquiring increased self-awareness, meta-processing, meta-cognitive and self-regulatory capacities. They develop selfdefinitions expressed in independent and interdependent self-schemas and related self-evaluative, event, and other-evaluative and cognitive and emotional processing capacities. Through this process, they acquire internal and external developmental assets. Developed self-evaluation capacities that help them explore their limits and potentials and cope with adversities. They selectively attune themselves to significant events that have relevance and importance to their developing self-definitions, self-schemas, self-evaluations, assets and existential concerns (e.g., Banaji \& Prentice, 1994; Fiske \& Taylor, 2013; Markus, 1977; Markus \& Kitayama, 2010; Oyserman, 2009).

Current status of our knowledge in this field fails/or poorly identify the differential effects of the various stressor types on different identities of the individual and the dynamics of their interactions. Further, the conceptual frameworks and empirical results that attempted to explore these interactional dynamics differed and are fragmented. Attempting the integration of a myriad of competing and overlapping theoretical models and related empirical research, in stress, trauma and identity fields, constitutes a formidable and challenging epistemological project. However, such an attempt may contribute to advance a transdisciplinary lens that organizes our knowledge and thinking on self, identity, and stress. We will use and further refine the emerging paradigm of developmentbased trauma framework (DBTF) to help tackle this integrative task.

\section{An Integrative Framework on Identity and Identity Traumas}

Constructing, deconstructing and reconstructing the self-identity components are related to the existence, maintenance and development of the individual's executive self with its emerging meta-cognitive and self-control capacities (see Figure 1). Agency seems to arise from both self-controlled and stimulus-controlled processes (e.g., Wang, Damen, \& Aarts, 2017). With the emerging agency, complex systems of identity emerge. An executive self-identity functions as the organizing and regulating executive agent that manages the self's dynamic hierarchy of identities (e.g., Bandura, 2006; Deci \& Ryan, 2010). It manages the development of agentic executive processing. Personal (and interpersonal) identity involves independent self-schemas which are central to the emotional and cognitive processing of interpersonal stressors and traumas. On another hand, social identity theory (SIT) (e.g., Tajfel \& Turner, 1979) suggested that identification with groups of belonging and interdependent self-schemas is central to emotional and cognitive processing especially in response to intergroup and collective (social) identity stressors. SIT proposes that group-based appraisal yields group-based emotions, and behavior (e.g., Mackie \& Smith, 2002). Self-identity 
is an information agent that process information about the world (e.g., Baumeister, Maranges, \& Vohs, 2018). Identities, personal or collective, as such, are pre-cognitive, pre-affective self-schemas and meta-representations that function to process and regulate perceptions, conducting appraisals/reappraisals, emotions and behavior (cf., e.g., Elmore \& Oyserman, 2012; Oyserman, Fryberg, \& Yoder, 2007; Randel, 2002; Reed, 2004; Oyserman et al., 2015). Further, identity implicates yearning for authenticity and the need to self-actualize, self-fulfill, and affirm the activated social or personal identity, promoting their goals and life projects.

Development-based trauma framework (DBTF) (Kira, 2001, Kira, 2010; Kira et al., 2008, Kira et al., 2013; Kira et al. 2011, Kira et al., 2014; Shuwiekh, Kira, \& Ashby, 2017) maps some of the linear and non-linear micro and macro dynamics behind the etiology of identity traumas negative or positive impact (see Figure 1, see also Appendix for terminology definitions). Human beings are self-aware dynamic systems that continually monitor internal and external processes through feedback and feedforward loops. They demonstrate nonlinear shifts from one state to another upon a threshold of external and/or internal pressures/stressors (e.g., Benight, Shoji \& Delahanty, 2017; Guastello, \& Liebovitch, 2009; Kaplan \& Garner, 2017; Kunnen, 2012). Current static models of identity cannot capture the nonlinear dynamic processes such as shifts in self-regulation and shifts in identity salience from identity to another within its complex hierarchical matrix of salient and dormant identities. Research on identity dynamics can benefit from a more dynamic hybrid linear and non-linear systems approach that is focused on the dynamic process of self-adaptation to extreme stressors across time. The dynamic hybrid approach opens the door to significant methodological advances in using the non-linear analytical methods.

DBTF expanded and integrated identity, existential and annihilation anxieties (EAA), and stress and trauma theories into a cohesive framework of identity trauma dynamics. Identity trauma framework (e.g., Kira, 2010) serves as a meta-theoretical heuristic that may orient future research on identity-related stressors. It is based on the separation/individuation and the development of autonomy and interdependence theories (e.g., Mahler, Pine, \& Bergman, 2000). It builds on Erikson's (1968) work on identity, Marcia's model of identity development (e.g., Marcia, 1980), and the model of identity processing styles (e.g., Berzonsky, 2008). Identity stressors/traumas are internal or external events or situations that threaten or challenge the existence, maintenance or development of one or more of the persons' salient identities, and/or its related assumptions, self-evaluations, and existing functional assets (compare: Oyserman, 2009a, 2009b, 2015; Fisher \& Oyserman, 2017). People usually react to stressors in ways that are congruent with their activated identities, related accessible self-schemas, and embedded valuations and related developmental assets. DBTF proposes three main stressor/trauma types that include pre-identity traumas, (e.g., attachment disruption), different identity stressor/trauma types that may be experienced with the emergence of the individuation process, and post-identity 


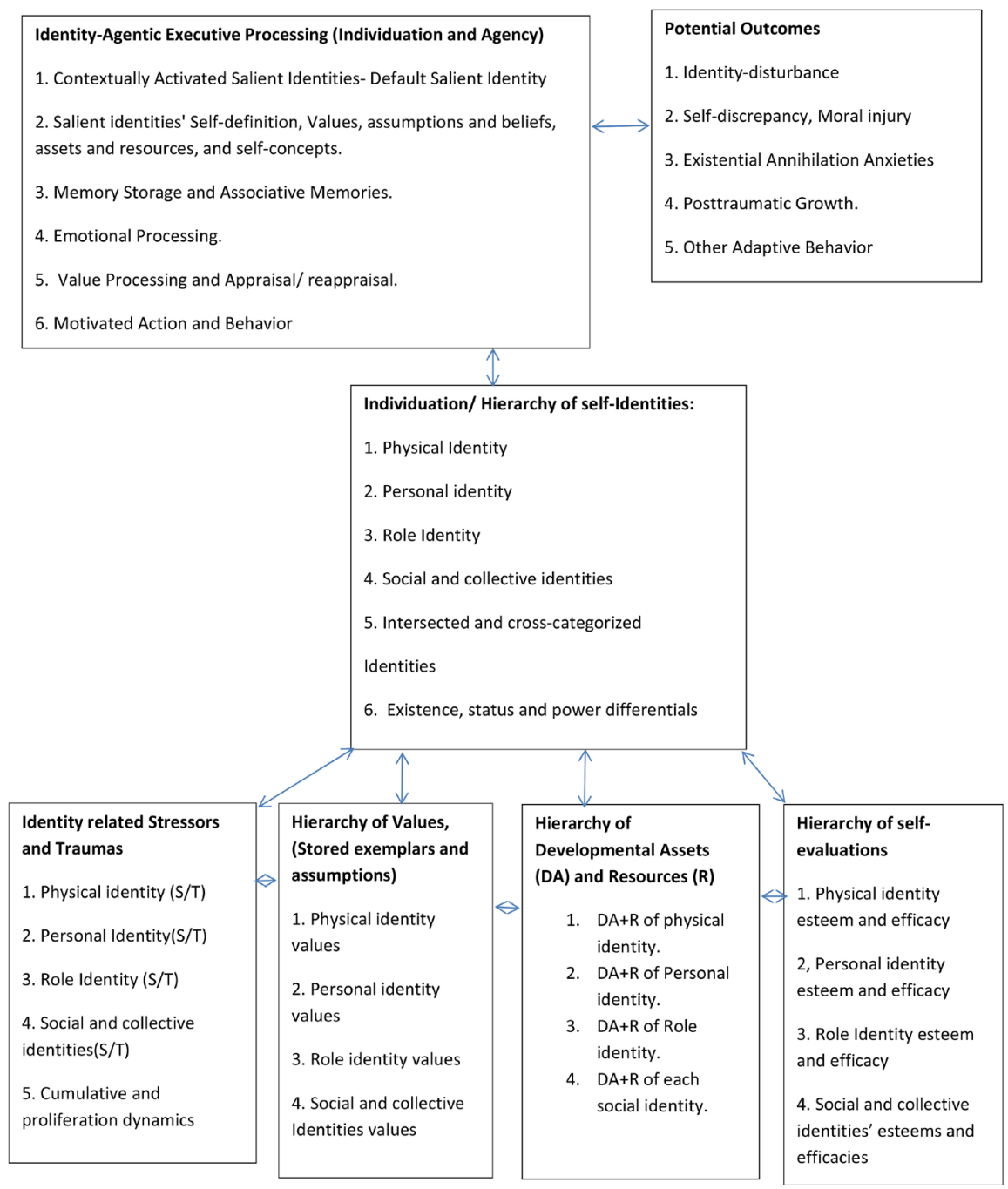

Figure 1. The conceptual model of identity linear and non-linear system micro dynamics. Note: $\mathrm{S} / \mathrm{T}=$ Stressors/Traumas; $\mathrm{DA}+\mathrm{R}=$ Developmental assets and Resources.

stressor/trauma of interdependence that reflects the wiring of the individual's complex personal and social connectome. Post-identity trauma types include secondary and tertiary stressor-trauma types. While secondary traumatization is the interpersonal transmission of stressor/trauma between connected persons, tertiary traumatization is the inter-generation transmission, intergroup transmission, and historical traumas. Both types of secondary and tertiary stressors/ traumas are related to the interdependence dynamics achieved through the individual's development. Identity stressors/traumas include personal identity stressor/trauma (PIT) (events that violate/threaten the person's agency, autonomy, and free will, e.g., sexual and physical abuse). Identity stressor/trauma, also, include role identities traumas (RIT) which are those that especially challenge his/ her self-actualization enterprises (e.g., failed business, fired from a job, forced out of school), or self-fulfillment venture (e.g., perceived failed generativity, and reproductive traumas, e.g., Jaffe \& Diamond, 2011). Role identity stressor/trauma can target at least two types of roles: social roles, for example, motherhood or fa- 
therhood with several responsibilities that achieve self-fulfillments, and educational and occupational roles that achieve self-actualization. They, also, include physical identity or survival stressor/trauma (PIST) (events that violate/threaten the person's physical existence, e.g., life-threatening event). The individual's physical identity and the link between identity development and threats to the body (Daniels \& Gillen, 2015), and to the body-esteem had attracted little attention in identity literature (Nelson, Kling, Wängqvist, Frisén, \& Syed, 2018). Further, identity stressor/trauma include a myriad of other social (or collective) identity stressor/trauma (CIST) (e.g., different discriminations such as ethnic, racial, and gender discriminations, different social-structure violence (e.g. poverty and relative deprivation), and intergroup conflicts (e.g., torture) (Kira, 2010, Kira et al., 2018). Most of such types of social or collective identity stressor/trauma are perpetrated by micro and macro systems and groups or their representative members, compared to other trauma types that are perpetrated primarily by individuals (Kira, 2017; Kira et al., 2014; Kira, Shuwiekh et al., 2018). Further, most of them are chronic and continuous (Kira et al., 2013). Finally, the advent of globalization, associated with the communication revolution and the spread of smartphones, led to the increased cyber-socialization. New types of virtual and actual personal and social (collective) identities are emerging (c.f., e.g., Clemmitt, 2006; Olivier, 2011), with new various cyber stressors/traumas (e.g., identity theft). Cultural and dual identities emerged with the widespread of internal migration, immigration, and asylum-seeking. Different cultural exposures yielded different social loyalties and identities and added up to the mix of the person's identity hierarchy and related stressors and traumas. For example, gaining refugee status, or naturalization is in itself an acquisition of a new social identity.

Identity trauma integrative framework differs from other approaches by theorizing identity system as a dynamic linear/non-linear system that manages at least three microdynamics and other three macro dynamics. First microdynamics is the processes of activation/inhibition of the salience of different identities upon exposure to different identity stressors and traumas. Second, are the dynamics of activation or inhibitions of varying event appraisals/reappraisals, selfappraisals/reappraisals processes, and the selective mobilization of core developmental assets related to the activated (or default) identity. The third is the activation of existential anxieties due to actual or perceived threats to the existence, maintenance or development of one or more of the person's identities. Finally, the theory goes beyond single trauma paradigm and its microdynamics to the macro dynamics of traumatization, such as cumulative trauma and trauma proliferation dynamics and the interaction between identity, pre- and post-identity traumas in the mechanisms leading to post-trauma identity development. In the following sections, we will discuss each of these main dynamics.

\subsection{Micro Dynamics}

a) The dynamic activation/inhibition of the salience of different identities upon exposure to different identity stressors and traumas: 
Different identities belong to the same person' agentic self (or self-identity). They intersect in a dynamic hierarchical structure, with some identities are more salient and other are more dormant, depending on the activating events or the importance the individual assign to each by default. The salient identities by default or by activating events are chronically accessible being the focused lens of appraising and responding to the relevant stressors.

Identity trauma theory proposes that what constitutes the "me" aspect of the self is not constant but differently activated and constructed on a moment-tomoment basis. There is extensive evidence that the identity heuristics are context specific and may be triggered by environmental stressors (Gilovich, Griffin, \& Kahneman, 2002). The different external or internal stressors and traumas, and the contextual constraints and affordances differently activate the salience of one identity or the other (and its related self-schemas, beliefs, values, and internal and external developmental assets and resources). The Agentic self's different identities are organized within a multi-level dynamic hierarchy with its structured gradients according to the salience/dormancy and the current situational relevance. Identity-centrality (identity salience), identity-uncertainty, subgroup, and superordinate group identities describe some of the identity characteristics within the hierarchy. The proportional relevance and importance of an identity to a person's executive self, as well as the type and severity of threats to an identity by an activating stressor, contributes to its salience. Threats to identity range in its severity, with the most severe, are the existential threats. The linear/nonlinear dynamic system approach to identity assumes that the self-system manages the hierarchy of identities and may switch across time in a discontinuous manner with threshold shifts from one identity to another under exposure to different types of stressors. The self-system contextually activates the relevant identities to be more salient, more accessible in regulating perceptions, appraisal/reappraisal, emotion, and behavior. It utilizes the values/goals and assumptions related to the salient (activated) identities to appraise/reappraise the emerging event/s. In post-event processing, she/he may reappraise and modify its initial appraisal, or suppress to ensure adequate control (Gross \& Thompson, 2007). It consults memories in the memory storage related or associated with the event/stressor. It processes different individual or collective negative or positive emotions triggered by the event/stressors. Also, it may initiate a motivated action and behavior in response to the stressor or the situation. The salient identity relevant self-schemas, related beliefs, values, and developmental assets are more accessible than other relatively dormant identities, directing appraisal, emotion, and behavior.

The activated identity can be a personal, physical, role, or one of the social or group identities, depending on the activating identity stressor/trauma. Each identity trauma type (physical, personal, role and group types) may elicit different dynamics that may cause different mental and physical health processes and outcomes. The salient (activated) identity became, with its linked content and 
processes, the current lens, and the agent in responding to such events or cues (c.f., Stryker, 1968). The higher the commitment (identity salience/centrality) to the activated identity, the higher is its potential salience as lens and agent for action. Related self-schemas and their associated contents and processes are accessible in memory, though not necessarily chronically accessible (Markus \& Kitayama, 1991; Markus \& Oyserman, 1989; Oyserman \& Lee, 2008; for reviews, Oyserman, 2017). The person may acquire a salient default identity in the cases of no severe stressor or traumas, or due to the chronic occurrences of specific types of traumas. Chronic personal identity traumas chronically activate personal identity and perpetually prime independent self-schemas that are related to autonomy, personal agency, and personal (or psychic) identity, leading to more individualism. On the other hand, collective identity when became chronically salient due to chronic collective identity traumas, perpetually activate the interdependent self-schemas that are related to the person's social identities, potentially leading to collectivism (c.f., e.g., Hogg, Terry, \& White, 1995). A default identity (independent or interdependent) may be chronically accessible to process ongoing events and stressors. The salient default identity should be empirically explored for each individual and group. A default identity can change with the type of actual or perceived contextual and chronic identity threats. Further, a dynamic switch in the salience of identity can be triggered by internal dynamics. For example, experiencing a failure to effectively deal with a particular personal identity trauma, may cause a switch in saliency to other personal identity (c.f., e.g., Murray, Lamarche, Gomillion, Seery, \& Kondrak, 2017), or to a collective identity (e.g., religion) making it more salient, or vice versa.

Further, coactivation of two or more identities occurs when a reaction to an event or situation is influenced by the meanings and roles associated with two (or more) identities simultaneously (e.g., Robin, Baumann, \& Kotik, 2018). Cognitively, an individual may experience the coactivated identities as compatible or in conflict. When two or more identity is coactivated, each activated identity is at risk of being set aside (or "identicide"); (Ashforth, Harrison, \& Corley, 2008). Some evidence suggests that identities at the individual level are more central than identities at relational or collective levels in individualistic societies (Sedikides, Gaertner, \& O’Mara, 2011). However, there is also evidence that collective mortality (death of one's in-group) has a greater impact than personal mortality (personal death), (especially) in collective cultures (Kashima, Halloran, Yuki, \& Kashima, 2004). The individual may also experience the coactivated identities as compatible, where information and meaning derived from each identity is mutually enhancing and enriching (Rothbard \& Ramarajan, 2009). An example of the coactivation dynamics is the coactivation of personal and physical identity traumas (e.g., sexual and physical abuse, or threats to kill) when committed in the context of political, intergroup violence. Torture, hate crimes, or discrimination can coactivate both personal and social or collective identity traumas. In this case of double-barrel trauma, personal and social identities intersect in potentially more severe traumatization dynamics. 
b) The dynamics of activation or inhibitions of an event appraisal/reappraisal, self-appraisal/reappraisal processes, and the selective mobilization of core developmental assets connected to the activated identity.

Self-identity is not only an information processing agent; it is a value and meaning-making processing agent (c.f., Baumeister \& Landau, 2018). Value processing (meaning-making) is one of the leading dynamics that are instrumental in coping with threats to identity. Each identity, in the identity hierarchy, has a unique (or shared) value processing (evaluating) system (VPS) that has a distinct structure, function, and processing capacity. VPS contains the pre-cognitive system of identity-relevant schemas, assumptions, beliefs, values, moral norms, implicit and idiosyncratic theories, narratives and a set of heuristics that constitute the identity structural contents and processes. There is empirical evidence that group identity, for example, triggers social norms and heuristics that prescribe specific behaviors and social roles (e.g., Bacharach, 2006).

Each identity's VPS contributes to evaluating the relevance and importance of an event to the activated identity (Kira, 1987; Shuwiekh, Kira, \& Ashby, 2017). Such process of appraisal and meaning-making are significant to health, well-being and individual development (e.g., Hooker, Masters \& Park, 2017, Park \& Baumeister, 2017). However, meaning-making is only an initial step of coping with the threat. There is empirical evidence that different identities may change the preferences in the decision-making process (e.g., Guala \& Filippin, 2017). Evidence suggests that individuals may also try to benefit from the experience, and or restore threatened needs or to pursue substitutes when needs or 'developmental assets" are challenged (e.g., Davis, Nolen-Hoeksema, \& Larson, 1998).

The person's different identities possess different value processing systems (VPSs) and core developmental assets (DAs) that may be identity type-specific. The meaning of an event means its implications to the salient identity (or identities). The event's meaning implicates its relevance and consequentiality to the person's activated identity (c.f., Baumeister \& Landau, 2018). The potential meaning of an event is determined by its potential impact on the identity existence, related current functional assets, and future valued goals, and life project. Also, the meaning-making of self-identity or self-evaluation is another important process.

Further, a self-evaluation system (self-esteem and efficacy or the perceived value and significance of self-identity) is an intricate part of the VPS. Self-evaluation is the totality of one's different self-concepts and self-schematizations (c.f., Horowitz, 2012). Developing self-awareness and self-reflective skills trigger the self-evaluation process in the various domains of functioning. Self-evaluation and resulted self-concept delineated the person's perception of his/her advantages and disadvantages and limitations and strengths confronting specific or general challenges to a specific identity/ies. However, inflated or deflated selfconcept (self-evaluation) can happen and may negatively impact the identity 
function. Hierarchy of self-concepts (core self-evaluations related to each identity) includes physical identity esteem and efficacy, personal identity esteem and efficacy, role identity esteem and efficacy, and social and collective identities esteem and efficacies. Conceptual and empirical research favors domain-specific self-esteem (self-concept) than an overall level of self-esteem (e.g., Schwinger, Schöne, \& Otterpohl, 2017). Research suggests a nonlinear relationship between self-esteem and behavioral health (e.g., Leary, Haupt, Strausser, \& Chokel, 1998; Kira, Shuwiekh \& Bujold-Bugeaud, 2016; Kira, Shuwiekh, Kucharska, \& Bujold-Bugeaud, 2018). Inflated self-esteem can lead to risk-taking behavior and externalizing behavior, while deflated self-esteem can lead to depression and internalizing behavior.

Further, the significance of a person's life is the search for a role or calling that is meaningful for the whole person or the default or salient identity. Life is rather meaningful when the person achieved or worked and sacrificed enough to reach goals sought by his/her salient identities. Goals related to personal, role/status, and social (collective) identities are all involved in the meaning-making process. The social identity goals play an integral role in scaffolding personal meaning (Baumeister \& Landau, 2018). Existential meaning involves purpose, value, mattering, continuity, and coherence of the activated identity (e.g., Baumeister \& Landau, 2018), and establishing the significance and the authenticity of an identity (Chen, 2018).

One of the important trajectories of the negative impact of identity stressors may occur when relevant identity stressors violate the activated identity-related assumptions, self-definition, values, beliefs, idiosyncratic and implicit theories, and moral norms threatening identity authenticity. As the term is typically used, authenticity refers to the degree to which a particular behavior is congruent with a person's attitudes, beliefs, values, motives, and other dispositions (e.g., Chen, 2018). Different ISTs can shake the particular identity-related value processing system's (VPS) equilibrium, shattering its assumptions (c.f., Janoff-Bulman, 2010), values, and implicit theories, causing disturbances in self-organization and systemic dynamical chaos. Such chaos can perturb the appraisal and emotion regulation processes, as well as motivated behavior. Such chaos can recalibrate a person's response to be out of his/her values and moral norms' range. Identity disturbance refers to a severe form of identity pathology. Despite clear relevance to psychological distress, existing explanatory models of identity pathology are scant and poorly integrated with modern clinical science (Kaufman \& Crowell, 2018). Identity disturbances and related pathologies may include self-discrepancies, moral injuries, and related emotional and behavioral disturbances (e.g., Higgins, Bond, Klein, \& Strauman, 1986; Litz et al., 2009; Strauman \& Higgins, 1987). Self-discrepancy (the discrepancy between authentic self-identity and perceived identity in this case), and moral injury were found to be associated with neuroticism, maladaptive coping, and negative affect as well as higher level indicators of psychological maladjustment and disorder (see Stoeber \& Otto, 2006, for a comprehensive review). It was found to be associated with neg- 
ative posttraumatic growth (Shuwiekh et al., 2017). The crisis of meaning found to predict suicidality in youth independently of depression and other potential risk factors (Schnell, Gerstner, \& Krampe, 2018).

Each identity (and the agentic person) strives to retain, protect, and build competencies, assets, and resources that they can utilize to increase their self-efficacy (and self and environment control) dealing with challenges. The potential or actual loss of these valued assets, resources and power are one of the significant identity threats (c.f., Hobfoll, 1989).

Core developmental assets (DAs) include two kinds: internal DA and external DA (extension resources). Internal DAs include (but not limited to) will to live, exist, survive, succeed, and thrive (WTELS). WTELS is one of the individual's emerging and primal developmental assets (Kira, Lewandowski et al., 2014; Schopenhauer, 1992). WTELS is the master motivator, and at the center stage in the science of motivation, that is still missing in current theories of motivation. New research of WTELS in adolescents, found evidence that "WTELS" is the source for coping and is strongly related to resiliency and posttraumatic growth. It was associated with a decrease in depression, PTSD, and comorbid complex mental health syndromes, as well as with improved physical health (Kira, Alawneh, Aboumediene, Lewandowski, \& Laddis, 2014; Carmel, 2011).

Further, internal DAs include self- and environment-control which comprise personal autonomy and feeling and having executive control (i.e., personal identity). They, also, include a secure attachment (or alternatively different types of attachment styles), the status of the person's roles fulfillment and achievements, and his/her personal and collective self-concepts (i.e., self-efficacy and self-esteem). They include the developed/ developing values, moral norms, and belief systems. Additionally, self-reflective, empathy, mentalizing, and self-monitoring, self-transcendence, and differentiation (detachment) capacities are among the potential internal assets. Internal DAs, also, include belonging, and interdependence capacities as well as social competence and psychosocial maturity. Interdependence capacities may include seeking, providing and receiving social and material support. Further, internal DAs include the person's genetics, predispositions, and able body's functioning organs that were developed across the lifespan, together with the person's brain, related neurological and physiological systems as well as associated cognitive and emotional processing and decision-making capacities (Kira, Lewandowski, Chiodo, \& Ibrahim, 2014). They may also include developed socio-economic-status, education, and positive attitudes and dispositions and futuristic orientation, (c.f., e.g., Pashak, Handal, \& Scales, 2018; Scales \& Leffert, 2004; Scales et al., 2016). On the other hand, extension resources (external assets) may include available social support, family structure, material and environmental resources, and social systems interventions (for a review of different resource theories see Hobfoll, 2002).

Developmental assets are fluid as they emerge, grow and, or decline with challenges and across the natural course of lifespan and development (c.f., Baltes, 1987). Internal developmental assets facilitate the development and use of 
external and situational assets. Developmental assets are, as such, prerequisites to optimal external resources utilization. The interplay between genetics, stressors, trauma types, its cumulative and proliferation dynamics, and resulted epigenetics unfolds over time to produce varieties and patterns of an individual's developmental assets and/or limitations. Individual's resiliency, distress tolerance and ability to cope with adversities are determined, in large part, by the status of his/her developmental assets. We propose a new approach and definition of resiliency that is measurable, which is the sum of the whole person's DAs, with different levels, portfolios, and poly-strengths of resiliency pertaining to each distinct identity. We can measure the overall resiliency and specific resiliencies for each identity, by sampling aspects of well-defined DAs for each. Empirical research would determine the relative contribution of each DA to an identity's resilience (c.f., e.g., Hamby, Grych, \& Banyard, 2018).

Further, there is an ongoing process of revising the contents of core selves (identities) and possible selves (developing identities) over the lifespan (Markus \& Nurius, 1986). Self-revision for different identities involves the ongoing adjustment of current self-representations of each identity to enhance their correspondence with feedback from the environment (Carroll, Agler, \& Newhart, 2015; Carroll, 2018), or to take advantage of lessons learned from different identities' stressors/ traumas exposure. Also, revisions in possible-self pursuits precipitate later revisions in core selves. Possible selves are more likely to succeed when derived from self-schemas that accurately represent one's actual “developmental “competencies (Markus \& Ruvolo, 1989).

To sum up, self-concepts, related valuation constructs (value processing system), and developmental assets are nested within identities and hierarchical links. Salient identities determine which self-concept and related valuation of essential assets, and strategies are accessible. Personal, physical, and different social (e.g., group identities) have different (or shared/overlapped) related valuated assets, goals, and self-concepts. At the same time, which identities come to be activated by the event (e.g., external or internal stressor or trauma) will trigger related assumptions, self-concept (self-esteem and efficacy), mobilizes assets and resource and enact the behavioral activation or inhibition process. Figure 1 summarizes the model of trauma microdynamics.

\section{c) The dynamics of existential anxieties activation}

Each identity has a unique or intersected existential strives and will-to-exist-live and survive. Identity traumas may threaten the sheer agentic autonomy or the mere existence of the salient (activated) identity. Existential threats are the most severe threats encountered by an identity. What makes an event traumatic is primarily determined by its potential or perceived existential threats to one or more of the person's salient identities. Concerns about the existence, maintenance and continuous emergence of one or more of the individual's own identities, starting in early adolescence, can escalate upon exposure to real or perceived existential threats. Traumatization, according to this framework, is a potential threat to and a challenge to an identity existence, to its assumptions or 
value processing system (VPS) and self-concepts and/or to its developmental assets, resources, and executive capacities. The potentially most significant mechanism of traumatization is the rise of existential annihilation anxiety (EAA). There is empirical evidence that the higher the salience of identity the higher is the EAA that may erupt upon CISTs exposure (Kira, Shuwiekh, Rice, Al Ibraheem, \& Aljakoub, 2017). Because of the importance of the dynamics of EAA, we will discuss its dynamics and consequences in detail.

Existential annihilation anxieties (EAA), which is almost ignored in current clinical science, significantly contribute to mediating the effects of identity traumas on different mental health disorders. There is initial empirical evidence that supports this hypothesis (Kira, Shuwiekh, Rice, Al Ibraheem, \& Aljakoub, 2017; Kira et al., 2012; Kira, Templin, Lewandowski, \& Shuwiekh, 2018; Kira, Shuwiekh, Kucharska, \& Al-Huwailah, 2019). Different existential threats may target different identities. Existential Psychic annihilation anxiety, fear of psychic destruction, and psychic annihilation may erupt upon exposure to personal identity traumas, such as rape, sexual abuse, and trafficking that threatens the person's autonomy and independence (e.g., Allen, Hurvich, \& Mcguire, 2017; Schiek-Gamble \& Hurvich, 2015; Hurvich, 2004). Similar existential anxieties may erupt upon exposure to events that threaten the person's established roles and self-actualization life achievements and goals. Also, existential fear of physical death may erupt upon exposure to the life-threatening or terminal events. Events that represent threats of physical destruction (e.g., combat, natural disaster) mostly represent the current dominant focus of trauma psychiatry and PTSD literature, as presented in Criterion A in PTSD (DSM IV, modified in DSM V, to include sexual abuse and secondary traumas in first responders). Further, collective (social) existential annihilation anxieties (CEAA) may erupt upon exposure to serious threats to one's group/s. CEAA, which is relatively an overlooked dynamics, emerges when one of the relevant social groups that the person closely identifies with is threatened, demeaned or assigned comparatively inferior status and power by other strong competitor or dominant groups. Hate crimes, slavery, Holocaust, genocides, and colonization are examples. Collective existential anxieties may trigger embitterment feelings in reaction to injustice, vilification, or humiliation (e.g., Linden \& Rotter, 2018).

Mortality salience theory (e.g., Greenberg et al., 1992) proposes that self-esteem serves as a buffering function for existential anxieties related to mortality salience. However, the intersection of different EAA from different existential threats goes beyond mortality salience. Proposing that self-esteem is a sufficient or the only potential buffer against mortality salience, let alone such different intersected existential anxieties is too simplistic and have an individualistic bias as it focuses only on the individual' physical mortality. We argue that self-esteem buffer hypothesis is questionable on several conceptual and empirical grounds. First self-esteem is part of the more general model of self-evaluation (self-beliefs or self-concepts, self-trust). Self-efficacy can be a functionally more powerful buffer (e.g., Bandura, 1982; Bandura, 1988). The concept of anxiety buffer is 
more complex and may include several components that empirically prove to contribute to the alleviation, blocking or buffering such existential anxieties (e.g., Hoelterhoff \& Chung, 2017). Self-esteem alone is one component of a cluster of anxiety buffer. First, we broaden the concept of existential anxiety to include personal, physical, role/status, and collective existential anxieties. The buffering cluster includes self-concept (self-evaluation that comprises self-efficacy and self-esteem, and self-trust), as well as the identities' value processing system (VPS), core assumptions, and core developmental assets that include will-to exist-live-survive leading a meaningful life (c.f., e.g., Hooker, Masters, \& Park, 2018). Such cluster functions to buffer identity-related existential annihilation anxieties at different levels of mortality (e.g., the inevitability of individual's death), and extinction salience (the inevitability of the group's demise across history). (Kira, 2002; Wohl, Branscombe, \& Reysen, 2010). The functioning of existential anxiety-buffer of mortality salience may be disrupted or threatened in the case of physical identity threats (e.g., Abdollahi, Pyszczynski, Maxfield, \& Luszczynska, 2011). Extinction salience existential anxiety-buffer functioning may break up upon exposure to such events like genocide and the Holocaust (e.g., Kira, 2002). Similar mechanisms are at work in the case of threats to personal or role identities. While the concepts of collective trauma and collective EAA were ignored for long in clinical and mainstream psychology, yet, political psychology started to recognize the importance of the concept in the Holocaust, genocides, and intergroup conflict studies (e.g., Hirschberger, Ein-Dor, Leidner, \& Saguy, 2016; Kira, 2002; Kira et al., 2012; Kira, Alawneh, Aboumediene, Lewandowski, \& Laddis, 2014; Kira et. al, 2018; Shrira, 2015; Yair, 2014; Wohl, Branscombe, \& Reysen, 2010). Existential anxiety about an identity loss can have more severe mental health consequences than PTSD, increasing comorbidities and complex syndromes.

Mortality and extinction saliences and other identity-related EAA can intersect, amplifying each other and creating reigning negative dynamics. However, extinction salience of the group can be more powerful and overrule mortality salience. There is empirical evidence that collective mortality (death of one's in-group) has a more significant impact than personal mortality (personal death), (especially) in collectivist cultures (Kashima, Halloran, Yuki, \& Kashima, 2004). Individual may sacrifice his/her physical self for the perceived survival of the group. We propose that Lone wolf phenomena (in terrorism research) may be explained, at least in part, by the primacy of group extinction salience, as a powerful motivator for such highly group-identified extremists.

A myriad of empirical studies that span across the trauma field, substantiated the adverse mental health effects of various violated personal identities (e.g., sexual abuse, child abuse, and neglect, rape). Also, on different violated physical identities (e.g., life-threatening events), and on role identities. Empirical studies have focused on various violated collective identities including racial identity ethnic identity, Native American identity (e.g., Omidy, 2012), and gender identity (e.g., Kira et al., 2015; Kira, Shuwiekh, \& Bujold-Bugeaud, 2017), and found 
that social identities violations are linked to adverse mental health outcomes. The results of meta-analyses (Pascoe \& Smart Richman, 2009) have also supported significant positive associations between identity violations and internalizing and externalizing disorders, general distress, depressive symptoms, anxiety, substance abuse, anger, psychosis, as well as negative associations with happiness, life satisfaction, and mastery. A growing literature is addressing the effects of virtual and cyberidentity traumas (e.g., Wright, 2015). A comprehensive review is beyond our scope.

\subsection{Macro Dynamics: Cumulative Stressors/Traumas, Stressors, and Traumas Proliferation and pre- and Post-Identity Traumas Interaction with Identity Stressors and Traumas}

Research and conceptual work in stressors and traumas macro dynamics is still in its inception. The current research identified at least three major dynamics: the cumulative intersected identity stressors and traumas, the proliferation of different identity (and non-identity) stressors and trauma and the interaction dynamics between pre-identity, identity, and post-identity traumas.

\section{a) Cumulative Stressors/Traumas dynamics}

The cumulative effects of each of the different identity trauma types and their intersection in a total cumulative impact have been studied. There is convincing evidence of the cumulative negative effects of some personal identity trauma (i.e., child poly-victimization) on mental and physical health (e.g., Finkelhor, Ormrod, \& Turner, 2007). Further, there is recent evidence of the cumulative negative effects of collective identity trauma on mental health (). There is convincing replicated evidence of the serious negative effects of cumulative stressors (that include pre-identity, identity, and post-identity traumas) (e.g., Awad, Kia-Keating, \& Amer, 2019; Cloitre et al., 2009; Kira et al., 2008, Kira, Fawzi \& Fawzi, 2013; Kira, Omidy \& Ashby, 2014, Kira, Lewandowski, Somers, Yoon, \& Chiodo, 2012; Martin, Cromer, DePrince, \& Freyd, 2013; Kira, 2004). The cumulative effects involve, in addition to the linear dose-response model generally observed in single trauma impact, a non-linear threshold model of causality. The accumulation of stressors' impact reaches a threshold where the last stressor/trauma becomes the "straw that broke the camel's back" breaching the threshold of distress tolerance. This non-linear threshold model presumes that individuals have different breaking points. Even for people with higher distress tolerance, enough cumulative dynamics can cause the person to "break". These nonlinear shifts from one state to another can happen upon exposure to external and internal pressures/stressors (e.g., Benight, Shoji \& Delahanty, 2017; Kira \& Wroble, 2016; Zeeman, 1976) and the most recent stressor (or chain of stressors) can falsely appear as the direct cause of the disorder. Armey and Crowther (2008), comparing a linear versus a non-linear model of aversive self-awareness, dissociation, and non-suicidal self-injury, found that the non-linear model evidenced a better fit to the data, accounting for 6 times the variance (66\%) than the linear model (9\% - 10\%). The non-linear models of the relationship between 
cumulative trauma and PTSD explained over three times the variance explained by the linear model indicating a threshold cumulative dynamic.

b) Stressors/Traumas Proliferation Dynamics:

Proliferation means that an event/s may predict other subsequent events in a chain-reaction manner over a period of time or over life-span. Studies on stressor and trauma proliferation (Kira et al., 2018; Kira, Lewandowski, Chiodo, \& Laddis, 2016) identified two trauma proliferation pathways: Pre-identity traumas

(e.g., attachment traumas) pathway, and the collective (social) identity stressors and traumas (CIST) pathway. Each independently predicted (directly and through mediators) personal identity trauma (PIT), role identity trauma, and physical identity or survival trauma (PIST) and secondary trauma (SIT). The pattern of proliferation was configurally invariant across different cultural groups and strictly or strongly invariant across genders.

\section{c) Identity Stressors Interaction Dynamics:}

The interaction between pre-identity, identity, and post-identity trauma, which represent the total traumatization dynamics, is still very lacking focus in current research. The interaction means identifying the predictive, mediating and moderating identity stressors/traumas that impact mental health. In a recent study (Kira et al., 2018), collective identity stressors/traumas (CIST) found to predict directly and indirectly (through mediators) existential annihilation anxieties (EAA), PTSD, and cumulative trauma-related disorders (CTD). It is surprising that oppression and discriminations that start with the emergence of a person's identity early in adolescence and continue with him/her the rest of the lifespan are overlooked in the PTSD literature (e.g., Holmes, Facemire, \& DaFonseca, 2016; Reisner et al., 2016). Physical/survival stressors/traumas (PIST) and personal identity traumas (PIT) were significant mediators of CIST's effects on PTSD and CTD. Physical identity or survival trauma was a significant mediator of CIST effects on EAA. Serial mediation analysis indicated several potential significant trajectories of the effects of CIST on PTSD and CTD via physical identity or survival trauma (PIST) or personal identity trauma or both, and via PIST on EAA. Pre-identity traumas (attachment traumas (ATT) moderated the mediated effects of CIST on PTSD and CTD via personal identity trauma (PIT). Secondary traumas (SIT) moderated CIST mediated effects on PTSD via PIT and PIST, and on EAA via PIST. Further, recent studies found that pre-identity traumas (i.e., attachment traumas), and post-identity trauma (e.g., secondary traumas) moderate the effects of CIST on mental health (Kira et al., 2018). Future research needs to develop a new focus on these global interaction dynamics between different stressor/trauma types across life-span.

\section{Conclusion}

The growing body of fragmented conceptual models and empirical findings on identity and identity stressors and traumas begs for a bold conceptual and empirical integration to advance the field. We described a unifying dynamic linear 
and non-linear system's approach to identity, its structure, and dynamics. The proposed dynamic system model integrated several paradigms and empirical findings on stress, trauma, and identity, applying, as a starting point, the individuation revolution that a person leads in her/his developmental path to adulthood. Current work refined the development-based identity theory that conceptually integrated identity stressors and traumas. We examined identity stressor/ trauma paradigm identifying the different types of identity traumas and the four main dynamic non-linear processes that manage the interaction between different identities and identity, pre-identity (e.g., attachment disruption) and postidentity (secondary and tertiary) stressors/traumas. The overarching goal was to provide a coherent and critical integration of the diverse theoretical models and empirical findings on identity and identity stressors and traumas that may help guide future empirical research. More attempts for conceptual and empirical refinement and integration are needed to advance our understanding of the dynamics of identity development.

Future research may explore the differential impact of different identity trauma types to provide a robust understanding of their micro and macro dynamics of each. Further, identity traumas intersect and dynamically interact with each other and with other pre-identity traumas (e.g., attachment traumas), and postidentity secondary (e.g., indirect and vicarious traumas) and tertiary traumas (e.g., historical and cross-generation transmitted traumas). The cumulative and macro dynamics of different stressors and intersected or proliferated traumas are a missing valid approach to studying their overall impact than only studying an isolated single identity trauma (e.g., Cloitre et al., 2009; Kira et al., 2008, Kira et al, 2018). This is especially true for those who were multiply traumatized (e.g., Stein, Wilmot, \&Solomon, 2016).

Current model has practical and theoretical significance in identifying the different types of identity traumas and the four main dynamic non-linear processes that manage the interaction between different identities and self-identity, pre-identity (e.g., attachment disruption) and post-identity (secondary and tertiary) stressors/traumas. This is the first attempt to integrate the theories and empirical research in the field of identity and provide an innovative framework for different identity pre and post-identity traumas. However, current attempt is limited with the scope and framework we developed within a vast field of theories and empirical research in the fast developing field of self-identity. Future studies can focus on further development of the integrative work and its components and empirically test its premises.

\section{Conflicts of Interest}

The author declares no conflicts of interest regarding the publication of this paper.

\section{References}

Abdollahi, A., Pyszczynski, T., Maxfield, M., \& Luszczynska, A. (2011). Posttraumatic 
Stress Reactions as a Disruption in Anxiety-Buffer Functioning: Dissociation and Responses to Mortality Salience as Predictors of Severity of Posttraumatic Symptoms. Psychological Trauma: Theory, Research, Practice, and Policy, 3, 329-341. https://doi.org/10.1037/a0021084

Allen, R., Hurvich, M., \& Mcguire, H. (2017). Diagnostic Utility of the Hurvich Experience Inventory/50. Psychoanalytic Psychology, 34, 271-278. https://doi.org/10.1037/pap0000067

Ashforth, B. E., Harrison, S. H., \& Corley, K. G. (2008). Identification in Organizations: An Examination of Four Fundamental Questions. Journal of Management, 34, 325-374. https://doi.org/10.1177/0149206308316059

Awad, G. H., Kia-Keating, M., \& Amer, M. M. (2019). A Model of Cumulative Racial-Ethnic Trauma among Americans of Middle Eastern and North African (MENA) Descent. American Psychologist, 74, 76-87. https://doi.org/10.1037/amp0000344

Bacharach, M. (2006). Beyond Individual Choice: Teams and Frames in Game Theory. Princeton: Princeton University Press.

Baltes, P. B. (1987). Theoretical Propositions of Life-Span Developmental Psychology: On the Dynamics between Growth and Decline. Developmental Psychology, 23, 611-626. https://doi.org/10.1037/0012-1649.23.5.611

Banaji, M. R., \& Prentice, D. A. (1994). The Self in Social Contexts. Annual Review of Psychology, 45, 297-332. https://doi.org/10.1146/annurev.ps.45.020194.001501

Bandura, A. (1982). Self-Efficacy Mechanism in Human Agency. American Psychologist, 37, 122. https://doi.org/10.1037/0003-066X.37.2.122

Bandura, A. (1988). Self-Efficacy Conception of Anxiety. Anxiety Research, 1, 77-98. https://doi.org/10.1080/10615808808248222

Bandura, A. (2006). Toward a Psychology of Human Agency. Perspectives on Psychological Science, 1, 164-180. https://doi.org/10.1111/j.1745-6916.2006.00011.x

Baumeister, R. F., \& Landau, M. J. (2018). Finding the Meaning of Meaning: Emerging Insights on Four Grand Questions. Review of General Psychology, 22, 1-10. https://doi.org/10.1037/gpr0000145

Baumeister, R. F., Maranges, H. M., \& Vohs, K. D. (2018). Human Self as Information Agent: Functioning in a Social Environment Based on Shared Meanings. Review of General Psychology, 22, 36-47. https://doi.org/10.1037/gpr0000114

Benight, C. C., Shoji, K., \& Delahanty, D. L. (2017). Self-Regulation Shift Theory: A Dynamic Systems Approach to Traumatic Stress. Journal of Traumatic Stress, 30, 333-342. https://doi.org/10.1002/jts.22208

Berzonsky, M. D. (2008). Identity Formation: The Role of Identity Processing Style and Cognitive Processes. Personality and Individual Differences, 44, 645-655. https://doi.org/10.1016/j.paid.2007.09.024

Blos, P. (1962). On Adolescence. New York: Free Press.

Carmel, S. (2011). The Will to Live as an Indicator of Well-Being and Predictor of Survival in Old Age. In L. W. Poon, \& J. Cohen-Mansfield (Eds.), Understanding WellBeing in the Oldest Old (pp. 281-289). New York: Cambridge University Press.

Carroll, P. J. (2018). The Reciprocal Path from Possible Self to Core Self-Revision. Review of General Psychology, 22, 264-277. https://doi.org/10.1037/gpr0000139

Chen, S. (2018). Authenticity in Context: Being True to Working Selves. Review of General Psychology.

Clemmitt, M. (2006). Cyber Socializing. CQ Press.

Cloitre, M., Stolbach, B. C., Herman, J. L., van der Kolk, B., Pynoos, R., Wang, J. et al. 
(2009). A Developmental Approach to Complex PTSD: Childhood and Adult Cumulative Trauma as Predictors of Symptom Complexity. Journal of Traumatic Stress, 22, 399-408. https://doi.org/10.1002/jts.20444

Daniels, E. A., \& Gillen, M. M. (2015). Body Image and Identity: A Call for New Research. In K. C. McLean, \& M. Syed (Eds.), The Oxford Handbook of Identity Development (pp. 406-422). New York: Oxford University Press.

Davis, C. G., Nolen-Hoeksema, S., \& Larson, J. (1998). Making Sense of Loss and Benefiting from the Experience: Two Construals of Meaning. Journal of Personality and Social Psychology, 75, 561-574. https://doi.org/10.1037/0022-3514.75.2.561

Deci, E. L., \& Ryan, R. M. (2010). Self-Determination. Hoboken, NJ: John Wiley \& Sons, Inc. https://doi.org/10.1002/9780470479216.corpsy0834

Elmore, K. C., \& Oyserman, D. (2012). If "We" Can Succeed, "I" Can too: Identity-Based Motivation and Gender in the Classroom. Contemporary Educational Psychology, 37, 176-185. https://doi.org/10.1016/j.cedpsych.2011.05.003

Erikson, E. H. (1968). Identity. Norton.

Finkelhor, D., Ormrod, R. K., \& Turner, H. A. (2007). Poly-Victimization: A Neglected Component in Child Victimization. Child Abuse \& Neglect, 31, 7-26. https://doi.org/10.1016/j.chiabu.2006.06.008

Fisher, O., \& Oyserman, D. (2017). Assessing Interpretations of Experienced Ease and Difficulty as Motivational Constructs. Motivation Science, 3, 133-163. https://doi.org/10.1037/mot0000055

Fiske, S. T., \& Taylor, S. E. (2013). Social Cognition: From Brains to Culture. Thousand Oaks, CA: Sage.

Galliher, R. V., McLean, K. C., \& Syed, M. (2017). An Integrated Developmental Model for Studying Identity Content in Context. Developmental Psychology, 53, 2011-2022. https://doi.org/10.1037/dev0000299

Gilovich, T., Griffin, D., \& Kahneman, D. (2002). Heuristics and Biases: The Psychology of Intuitive Judgment. Cambridge: Cambridge University Press.

Greenberg, J., Solomon, S., Pyszczynski, T., Rosenblatt, A., Burling, J., Lyon, D., Simm, L., \& Pinel, E. (1992). Why Do People Need Self-Esteem? Converging Evidence That Self-Esteem Serves an Anxiety-Buffering Function. Journal of Personality and Social Psychology, 63, 913-922. https://doi.org/10.1037/0022-3514.63.6.913

Gross, J. J., \& Thompson, R. A. (2007). Emotion Regulation: Conceptual Foundations. In J. J. Gross (Ed.), Handbook of Emotion Regulation (pp. 3-24). New York: Guilford Press.

Guala, F., \& Filippin, A. (2017). The Effect of Group Identity on Distributive Choice: Social Preference or Heuristic? The Economic Journal, 127, 1047-1068. https://doi.org/10.1111/ecoj.12311

Hamby, S., Grych, J., \& Banyard, V. (2018). Resilience Portfolios and Poly-Strengths: Identifying Protective Factors Associated with Thriving after Adversity. Psychology of Violence, 8, 172-183. https://doi.org/10.1037/vio0000135

Higgins, E. T., Bond, R. N., Klein, R., \& Strauman, T. (1986). Self-Discrepancies and Emotional Vulnerability: How Magnitude, Accessibility, and Type of Discrepancy Influence Affect. Journal of Personality and Social Psychology, 51, 5-15. https://doi.org/10.1037/0022-3514.51.1.5

Hirschberger, G., Ein-Dor, T., Leidner, B., \& Saguy, T. (2016). How Is Existential Threat Related to Intergroup Conflict? Introducing the Multidimensional Existential Threat (MET) Model. Frontiers in Psychology, 7, 1877. 
https://doi.org/10.3389/fpsyg.2016.01877

Hobfoll, S. E. (1989). Conservation of Resources: A New Attempt at Conceptualizing Stress. American Psychologist, 44, 513-524. https://doi.org/10.1037/0003-066X.44.3.513

Hobfoll, S. E. (2002). Social and Psychological Resources and Adaptation. Review of General Psychology, 6, 307-324. https://doi.org/10.1037/1089-2680.6.4.307

Hoelterhoff, M., \& Chung, M. (2017). Death Anxiety Resilience; a Mixed Methods Investigation. Psychiatric Quarterly, 88, 635-651. https://doi.org/10.1007/s11126-016-9483-6

Hogg, M. A., Terry, D. J., \& White, K. M. (1995). A Tale of Two Theories: A Critical Comparison of Identity Theory with Social Identity Theory. Social Psychology Quarterly, 58, 255-269. https://doi.org/10.2307/2787127

Holmes, S. C., Facemire, V. C., \& DaFonseca, A. M. (2016). Expanding Criterion A for Posttraumatic Stress Disorder: Considering the Deleterious Impact of Oppression. Traumatology, 22, 314-321. https://doi.org/10.1037/trm0000104

Hooker, S. A., Masters, K. S., \& Park, C. L. (2017). A Meaningful Life Is a Healthy Life: A Conceptual Model Linking Meaning and Meaning Salience to Health. Review of General Psychology, 22, 11-24. https://doi.org/10.1037/gpr0000115

Horowitz, M. J. (2012). Self-Identity Theory and Research Methods. Journal of Research Practice, 8, 1-11.

Hurvich, M. (2004). Psychic Trauma and Fears of Annihilation. In D. Knafo (Ed.), Living with Terror, Working with Trauma: A Clinician's Handbook (pp. 51-66). Northvale, NJ: Aronson.

Janoff-Bulman, R. (2010). Shattered Assumptions. Simon and Schuster.

Kaplan, A., \& Garner, J. K. (2017). A Complex Dynamic Systems Perspective on Identity and Its Development: The Dynamic Systems Model of Role Identity. Developmental Psychology, 53, 2036-2051. https://doi.org/10.1037/dev0000339

Kashima, E. S., Halloran, M., Yuki, M., \& Kashima, Y. (2004). The Effects of Personal and Collective Mortality Salience on Individualism: Comparing Australians and Japanese with Higher and Lower Self-Esteem. Journal of Experimental Social Psychology, 40, 384-392. https://doi.org/10.1016/j.jesp.2003.07.007

Kaufman, E. A., \& Crowell, S. E. (2018). Biological and Behavioral Mechanisms of Identity Pathology Development: An Integrative Review. Review of General Psychology, 22, 245-263. https://doi.org/10.1037/gpr0000138

Kira, I. (2001). Taxonomy of Trauma and Trauma Assessment. Traumatology: An International Journal, 2, 1-14. https://doi.org/10.1177/153476560100700202

Kira, I. (2004). Secondary Trauma in Treating Refugee Survivors of Torture and Their Families. Torture, 14, 38-44.

Kira, I. (2010). Etiology and Treatments of Post-Cumulative Traumatic Stress Disorders in Different Cultures. Traumatology: An International Journal, 16, 128-141. https://doi.org/10.1177/1534765610365914

Kira, I. (2017). A Critical Outlook at Torture Definition, Structure, Dynamics, and Interventions: A Brief Research Report. Peace and Conflict: Journal of Peace Psychology, 3, 328-333. https://doi.org/10.1037/pac0000243

Kira, I. A., \& Wroble, N. H. (2016). Trauma: Stress, Coping, and Emerging Treatment Models. In M. M. Amer, \& G. H. Awad (Eds.), Handbook of Arab American Psychology. New York: Routledge.

Kira, I. A., Lewandowski, L., Chiodo, L., \& Laddis, A. (2016). Is Complicated Birth One of the Early Childhood Traumas? A Framework for Birthing Trauma, Its Impacts, and Proliferation. Psychology, 7, 426-443. https://doi.org/10.4236/psych.2016.73045 
Kira, I. A., Omidy, A. Z., \& Ashby, J. S. (2014). Cumulative Trauma, Appraisal, and Coping in Palestinian and American Indian Adults: Two Cross-Cultural Studies. Traumatology: An International Journal, 20, 119-133. https://doi.org/10.1037/h0099397

Kira, I. A., Shuwiekh, H., Al-Huwailah, A. H., Lewandowski, L., Alawneh, A.-W. N., Abou-Mediene, S., Aljakoub, J. et al. (2018). The Central Role of Social Identity in Oppression, Discrimination and Social-Structural Violence: Collective Identity Stressors and Traumas, Their Dynamics and Mental Health Impact. Peace and Conflict: Journal of Peace Psychology. https://doi.org/10.1037/pac0000363

Kira, I. A., Shuwiekh, H., Kucharska, J., Fawzi, M., Ashby, J. S., Omidy, A. Z., Abou-Mediene, S., \& Lewandowski, L. (2018). Trauma Proliferation and Stress Generation (TPSG) Dynamics and Their Implications for Clinical Science. American Journal of Orthopsychiatry, 88, 582-596. https://doi.org/10.1037/ort0000304

Kira, I. A., Templin, T., Lewandowski, L., \& Shuwiekh, H. (2018). A Conceptual Model and Measurement of Identity-Based, Existential Annihilation Anxieties (EAA). Psychology, 9, 1306-1328. https://doi.org/10.4236/psych.2018.96080

Kira, I., Abou-Mediene, S., Ashby, J., Odenat, L., Mohanesh, J., \& Alamia, H. (2013). The Dynamics of Post-Traumatic Growth across Different Trauma Types in a Palestinian Sample. Journal of Loss and Trauma: International Perspectives on Stress \& Coping, $18,120-139$.

Kira, I., Alawneh, A. N., Aboumediane, S., Mohanesh, J., Ozkan, B., \& Alamia, H. (2011). Identity Salience and Its Dynamics in Palestinians Adolescents. Psychology, 2, 781-791. https://doi.org/10.4236/psych.2011.28120

Kira, I., Alawneh, A., Aboumediene, S., Lewandowski, L., \& Laddis, A. (2014). Dynamics of Oppression and Coping from Traumatology Perspective: The Example of Palestinian Youth. Peace and Conflict: Journal of Peace Psychology, 20, 385-411. https://doi.org/10.1037/pac0000053

Kira, I., Ashby J. S., Lewandowski, L., Alawneh, A. N., Mohanesh, J., \& Odenat, L. (2013). Advances in Continuous Traumatic Stress Theory: Traumatogenic Dynamics and Consequences of Intergroup Conflict: The Palestinian Adolescents' Case. Psychology, 4, 396-409. https://doi.org/10.4236/psych.2013.44057

Kira, I., Fawzi, M., \& Fawzi, M. (2013). The Dynamics of Cumulative Trauma and Trauma Types in Adults Patients with Psychiatric Disorders: Two Cross-Cultural Studies. Traumatology: An International Journal, 19, 179-195. https://doi.org/10.1177/1534765612459892

Kira, I., Lewandowski, L., Chiodo, L., \& Ibrahim, A. (2014). Advances in Systemic Trauma Theory: Traumatogenic Dynamics and Consequences of Backlash as a Multi-Systemic Trauma on Iraqi Refugee Muslim Adolescents. Psychology, 5, 389-412. https://doi.org/10.4236/psych.2014.55050

Kira, I., Lewandowski, L., Somers, C., Yoon, J., \& Chiodo, L. (2012) PTSD, Trauma Types, Cumulative Trauma, and IQ: The Case of African American and Iraqi Refugee Adolescents. Psychological Trauma: Theory, Research, Practice, and Policy, 4, 128-139. https://doi.org/10.1037/a0022121

Kira, I., Lewandowski, L., Templin, T., Ramaswamy, V., Ozkan, B., \& Mohanesh, J. (2008a). Measuring Cumulative Trauma Dose, Types and Profiles Using a Development-Based Taxonomy of Trauma. Traumatology: International Journal, 14, 62-87. https://doi.org/10.1177/1534765608319324

Kira, I., Shuwiekh, H., \& Bujold-Bugeaud (2017). Toward Identifying the Etiologies of Gender Differences in Authoritarianism and Mental Health: An Egyptian Study. Peace and Conflict: Journal of Peace Psychology, 23, 183-188. 
https://doi.org/10.1037/pac0000206

Kira, I., Shuwiekh, H., Kucharska, J., \& Al-Huwailah, A. (2019). The Integrated Structural and Measurement Models of Existential Annihilation Anxieties (EAA) and Their Potential Contribution to Clinical Science: Two Studies.

Kira, I., Shuwiekh, H., Rice, K., Al Ibraheem, B., \& Aljakoub, J. (2017). A Threatened Identity: The Mental Health Status of Syrian Refugees in Egypt and Its Etiology. Identity: An International Journal of Theory and Research, 3, 176-190. https://doi.org/10.1080/15283488.2017.1340163

Kira, I., Somers, C., Lewandowski, L., \& Chiodo, L. (2012). Attachment Disruptions, IQ and PTSD in African American Adolescents (AAA): A Traumatology Perspective. Journal of Aggression, Maltreatment, and Trauma, 21, 665-690. https://doi.org/10.1080/10926771.2012.698377

Kira, I., Templin, T., Lewandowski, L., Ashby, J. S., Oladele, A., \& Odenat, L. (2012). Cumulative Trauma Disorder Scale: Two Studies. Psychology, 3, 643-656. https://doi.org/10.4236/psych.2012.39099

Kira, I., Templin, T., Lewandowski, L., Ramaswamy, V., Bulent, O., Mohanesh, J., \& Abdulkhaleq, H. (2012). Collective and Personal Annihilation Anxiety: Measuring Annihilation Anxiety AA. Psychology, 3, 90-99. https://doi.org/10.4236/psych.2012.31015

Kroger, J. (2007). Identity Development: Adolescence through Adulthood. Thousand Oaks, CA: Sage.

Kunnen, S. (2012). A Dynamic Systems Approach to Adolescent Development. London: Routledge/Psychology Press. https://doi.org/10.4324/9780203147641

Leary, M. R., Haupt, A. L., Strausser, K. S., \& Chokel, J. T. (1998). Calibrating the Sociometer: The Relationship between Interpersonal Appraisals and the State Self-Esteem. Journal of Personality and Social Psychology, 74, 1290-1299. https://doi.org/10.1037/0022-3514.74.5.1290

Linden, M., \& Rotter, M. (2018). Spectrum of Embitterment Manifestations. Psychological Trauma: Theory, Research, Practice, and Policy 10, 1-6. https://doi.org/10.1037/tra0000307

Litz, B. T., Stein, N., Delaney, E., Lebowitz, L., Nash, W. P., Silva, C., \& Maguen, S. (2009). Moral Injury and Moral Repair in War Veterans: A Preliminary Model and Intervention Strategy. Clinical Psychology Review, 29, 695-706. https://doi.org/10.1016/j.cpr.2009.07.003

Mahler, M. S., Pine, F., \& Bergman, A. (2000). The Psychological Birth of the Human Infant Symbiosis and Individuation. New York: Basic Books.

Marcia, J. E. (1980). Identity in Adolescence. Handbook of Adolescent Psychology, 9, 159-187.

Markus, H. (1977). Self-Schemata and Processing Information about the Self. Journal of Personality and Social Psychology, 35, 63-78. https://doi.org/10.1037/0022-3514.35.2.63

Markus, H. R., \& Kitayama, S. (1991). Culture and the Self: Implications for Cognition, Emotion, and Motivation. Psychological Review, 98, 224-253.

https://doi.org/10.1037/0033-295X.98.2.224

Markus, H. R., \& Kitayama, S. (2010). Cultures and Selves: A Cycle of Mutual Constitution. Perspectives on Psychological Science, 5, 420-430.

https://doi.org/10.1177/1745691610375557

Markus, H., \& Nurius, P. (1986). Possible Selves. American Psychologist, 41, 954-969. https://doi.org/10.1037/0003-066X.41.9.954

Markus, H., \& Ruvolo, A. (1989). Possible Selves: Personalized Representations of Goals. 
In L. S. Pervin (Ed.), Goal Concepts in Personality and Social Psychology (pp. 211241). Hillsdale, NJ: Lawrence Erlbaum.

Martin, C. G., Cromer, L. D., DePrince, A. P., \& Freyd, J. J. (2013). The Role of Cumulative Trauma, Betrayal, and Appraisals in Understanding Trauma Symptomatology. Psychological Trauma: Theory, Research, Practice, and Policy, 5, 110-118. https://doi.org/10.1037/a0025686

Murray, S. L., Lamarche, V. M., Gomillion, S., Seery, M. D., \& Kondrak, C. (2017). In Defense of Commitment: The Curative Power of Violated Expectations. Journal of Personality and Social Psychology, 113, 697-729. https://doi.org/10.1037/pspi0000102

Nelson, S. C., Kling, J., Wängqvist, M., Frisén, A., \& Syed, M. (2018). Identity and the Body: Trajectories of Body Esteem from Adolescence to Emerging Adulthood. Developmental Psychology, 54, 1159-1171. https://doi.org/10.1037/dev0000435

Olivier, B. (2011). Facebook, Cyberspace, and Identity. Psychology in Society, 41, 40-58.

Omidy, A. Z. (2012). The Influence of Cumulative Trauma, Binge Eating and Coping Styles on the General Health of American Indians. Stillwater, OK: Oklahoma State University.

Oyserman, D. (2009). Identity-Based Motivation: Implications for Action-Readiness, Procedural-Readiness, and Consumer Behavior. Journal of Consumer Psychology, 19, 250260. https://doi.org/10.1016/j.jcps.2009.05.008

Oyserman, D. (2017). Culture Three Ways: Culture and Subcultures within Countries. Annual Review of Psychology, 68, 435-463. https://doi.org/10.1146/annurev-psych-122414-033617

Oyserman, D., \& Lee, S. W. S. (2008). Does Culture Influence What and How We Think? Effects of Priming Individualism and Collectivism. Psychological Bulletin, 134, 311-342. https://doi.org/10.1037/0033-2909.134.2.311

Oyserman, D., Destin, M., \& Novin, S. (2015). The Context-Sensitive Future Self: Possible Selves Motivate in Context, Not Otherwise. Self and Identity, 14, 173-188. https://doi.org/10.1080/15298868.2014.965733

Oyserman, D., Fryberg, S. A., \& Yoder, N. (2007). Identity-Based Motivation and Health. Journal of Personality and Social Psychology, 93, 1011-1027. https://doi.org/10.1037/0022-3514.93.6.1011

Park, J., \& Baumeister, R. F. (2017). Meaning in Life and Adjustment to Daily Stressors. The Journal of Positive Psychology, 12, 333-341. https://doi.org/10.1080/17439760.2016.1209542

Pascoe, E. A., \& Smart Richman, L. (2009). Perceived Discrimination and Health: A Meta-Analytic Review. Psychological Bulletin, 135, 531-554. https://doi.org/10.1037/a0016059

Pashak, T. J., Handal, P. J., \& Scales, P. C. (2018). Protective Factors for the College Years: Establishing the Appropriateness of the Developmental Assets Model for Emerging Adults. Current Psychology, 37, 45-57. https://doi.org/10.1007/s12144-016-9488-1

Randel, A. E. (2002). Identity Salience: A Moderator of the Relationship between Group Gender Composition and Workgroup Conflict. Journal of Organizational Behavior, 23, 749-766. https://doi.org/10.1002/job.163

Reed, A. (2004). Activating the Self-Importance of Consumer Selves: Exploring Identity Salience Effects on Judgments. Journal of Consumer Research, 31, 286-295. https://doi.org/10.1086/422108

Reisner, S. L., Poteat, T., Keatley, J., Cabral, M., Mothopeng, T., Dunham, E., Baral, S. D. et al. (2016). Global Health Burden and Needs of Transgender Populations: A Review. 
The Lancet, 388, 412-436. https://doi.org/10.1016/S0140-6736(16)00684-X

Robin, J., Baumann, H. M., \& Kotik, J. (2018). Identity Coactivation: Person and Situation Influences and the Mediating Role of Experienced Conflict. Journal of Applied Social Psychology, 48, 411-423. https://doi.org/10.1111/jasp.12521

Rothbard, N. P., \& Ramarajan, L. (2009). Checking Your Identities at the Door? Positive Relationships between Nonwork and Work Identities. In L. M. Roberts, \& J. E. Dutton (Eds.), Exploring Positive Identities and Organizations: Building a Theoretical and Research Foundation (pp. 125-148). New York: Routledge.

Scales, P. C., \& Leffert, N. (2004). Developmental Assets: A Synthesis of the Scientific Research on Adolescent Development (2nd ed.). Minneapolis, MN: Search Institute.

Scales, P. C., Benson, P. L., Oesterle, S., Hill, K. G., Hawkins, J. D., \& Pashak, T. J. (2016). The Dimensions of Successful Young Adult Development: A Conceptual and Measurement Framework. Applied Developmental Science, 20, 150-174. https://doi.org/10.1080/10888691.2015.1082429

Schiek-Gamble, C., \& Hurvich, M. (2015). Fear of Psychic and Physical Destruction: The Relation of Child Abuse, Negative Life Events, and Adult Attachment to Annihilation Anxiety. Journal of the American Psychoanalytic Association, 63, NP27-NP33. https://doi.org/10.1177/0003065115594785

Schnell, T., Gerstner, R., \& Krampe, H. (2018). Crisis of Meaning Predicts Suicidality in Youth Independently of Depression. Crisis: The Journal of Crisis Intervention and Suicide Prevention, 39, 294-303. https://doi.org/10.1027/0227-5910/a000503

Schopenhauer, A. (1992). On the Will in Nature (Payne, E.F.J., Trans., Cartwright, D., Ed.). New York: Berg.

Schwinger, M., Schöne, C., \& Otterpohl, N. (2017). Structure of Contingent Self-Esteem: Global, Domain-Specific, or Hierarchical Construct? European Journal of Psychological Assessment, 33, 388-397. https://doi.org/10.1027/1015-5759/a000296

Sedikides, C., Gaertner, L., \& O’Mara, E. M. (2011). Individual Self, Relational Self, Collective Self: Hierarchical Ordering of the Tripartite Self. Psychological Studies, 56, 98-107. https://doi.org/10.1007/s12646-011-0059-0

Shrira, A. (2015). Transmitting the Sum of All Fears: Iranian Nuclear Threat Salience among Offspring of Holocaust Survivors. Psychological Trauma: Theory, Research, Practice, and Policy, 7, 364-371. https://doi.org/10.1037/tra0000029

Shuwiekh, H., Kira, I. A., \& Ashby, J. S. (2017). What Are the Personality and Trauma Dynamics That Contribute to Posttraumatic Growth? International Journal of Stress Management, 25, 181-194. https://doi.org/10.1037/str0000054

Stein, J. Y., Wilmot, D. V., \& Solomon, Z. (2016). Does One Size Fit All? Nosological, Clinical, and Scientific Implications of Variations in PTSD Criterion A. Journal of Anxiety Disorders, 43, 106-117. https://doi.org/10.1016/j.janxdis.2016.07.001

Stoeber, J., \& Otto, K. (2006). Positive Conceptions of Perfectionism: Approaches, Evidence, Challenges. Personality and Social Psychology Review, 10, 295-319. https://doi.org/10.1207/s15327957pspr1004_2

Strauman, T. J., \& Higgins, E. T. (1987). Automatic Activation of Self-Discrepancies and Emotional Syndromes: When Cognitive Structures Influence Affect. Journal of Personality and Social Psychology, 53, 1004-1014. https://doi.org/10.1037/0022-3514.53.6.1004

Stryker, S. (1968). Identity Salience and Role Performance: The Relevance of Symbolic Interaction Theory for Family Research. Journal of Marriage and the Family, 30, 558564. https://doi.org/10.2307/349494

Tajfel, H., \& Turner, J. C. (1979). An Integrative Theory of Intergroup Conflict. The So- 
cial Psychology of Intergroup Relations, 33, 74-88.

Wang, Y., Damen, T. G., \& Aarts, H. (2017). Uncovering Effects of Self-Control and Stimulus-Driven Action Selection on the Sense of Agency. Consciousness and Cognition, 55, 245-253. https://doi.org/10.1016/j.concog.2017.09.005

Wohl, M. J., Branscombe, N. R., \& Reysen, S. (2010). Perceiving Your Group's Future to Be in Jeopardy: Extinction Threat Induces Collective Angst and the Desire to Strengthen the Ingroup. Personality and Social Psychology Bulletin, 36, 898-910. https://doi.org/10.1177/0146167210372505

Wright, M. F. (2015). Cyber Victimization and Perceived Stress: Linkages to Late Adolescents' Cyber Aggression and Psychological Functioning. Youth \& Society, 47, 789-810. https://doi.org/10.1177/0044118X14537088

Yair, G. (2014). Israeli Existential Anxiety: Cultural Trauma and the Constitution of National Character. Social Identities, 20, 346-362. https://doi.org/10.1080/13504630.2014.1002390

Zeeman, E. C. (1976). Catastrophe Theory. Scientific American, 234, 65-83. https://doi.org/10.1038/scientificamerican0476-65 


\section{Appendix: Basic Terminology and Definitions of the Constructs and Dynamics of Developmental Stressors/Traumas Framework}

Cumulative Stressors (cross-sectional) $=$ Chronic Stressors + Acute Stressors (traumas) + life ordinary stressors (positive, negative or neutral)

Cross-sectional and sequential (longitudinal) Stressors trajectories

Physiological Stressors $<>$ Psychological Stressors $<>$ Social Stressors:

- Chronic Physiological Stressors <> Chronic Psychological Stressors <> Chronic Social Stressors $>$ Cumulative Chronic Stress Load.

- Acute (i.e., Traumatic) Physiological Stressors <> Acute Psychological Stressors $<>$ Acute Social Stressors $>$ cumulative Acute (traumatic) Stress Load.

- Total Cumulative Stressors Load = Chronic Stressors Load + Acute (traumatic) Stressors Load

\section{Types of Development related Stressors:}

Pre-identity stressors $=$ Prenatal physiological stressors + birthing Stressors (e.g., Complicated birth) physiological and psychological stressors + Attachment disruption and attachment styles (Psychological stressors) $+0-3$ child abuse and neglect (physiological and psychological stressors).

Identity Stressors $=$ Physical identity Stressors (physiological and psychological stressors) + Personal identity (Psychic) Stressors (primarily psychological stressors) + Role identity Stressors (self-actualization and self-fulfillment) (psychological and social stressors) + Social identity stressors (social and psychological stressors).

Social Identity Stressors = group identity stressors (e.g., genocide, holocaust, discriminations, oppression) + social structure status (violence) stressors (poverty-cast systems, slavery)

Post-identity (interdependence) stressors $=$ Secondary Stressors (crosspersons transmitted stressors) + Tertiary Stressors (cross-generations transmitted and historical stressors)

Stressors Basic Micro dynamics = The dynamic activation/inhibition of the salience of different identities and default identity $>$ The dynamics of activation or inhibitions of varying events appraisals and the selective mobilization of core developmental assets by the salient identity $>$ The dynamics of activation of existential anxieties in response to potential or perceived severe threats to the existence, maintenance or development of one or more of the person's identities.

\section{Stressors Basic Macro dynamics}

Pre-identity Stressors Load + Identity Stressors Load + Post-identity Stressors Load $>$ Stressors Macro dynamics

Stressors Macro dynamics = Stressors cumulative dynamics + Stressors proliferation dynamics + Stressors interaction dynamics (mediation - moderation). 